Maryna Gurenko (marinagurenko@yahoo.com)

Kyiv National University of Culture and Arts

\title{
Reasons for the spread of the glamour style in modern interiors, and the specifics of its manifestation
}

\author{
Powody rozpowszechniania stylu glamour \\ w nowoczesnych wnętrzach i specyfika \\ jego manifestacji
}

\begin{abstract}
The article analyses the origin of a peculiar phenomenon of glamour in different fields of human life and in various types of art. Based on the analysis of the source base, a direct connection of the appearance of glamour with the emergence of a new elite in the political arena was proven. The article has analysed the manifestations of glamour in interior design; it presents an assessment of this phenomenon and examples of the modern interior in the style of glamour.
\end{abstract}

Keywords: glamour, interior design, philosophical and culturological phenomenon

Streszczenie

W artykule zostały przeanalizowane źródła szczególnego zjawiska splendoru (glamour) w różnych dziedzinach życia człowieka i w różnych odmianach sztuki. Na podstawie przeanalizowania bazy źródłowej udowodniono bezpośrednie powiązanie powstania splendoru ze stanowieniem na politycznej arenie nowej elity. Przeanalizowano przejawy splendoru w designie wnętrz oraz przedstawiono ocenę tego zjawiska.

Słowa kluczowe: splendor (glamour), design wnętrz, zjawisko filozoficzne i kulturologiczne 


\section{INTRODUCTION}

In the present day, in the stylistic diversity of modern interiors, a separate 'glamour' style has emerged as an identification of refinement and treasures, and a demonstration of the social status of a customer and his or her personal image. The use of modernised elements of the styles of previous epochs which personified magnificence and pomposity became widespread. Baroque and Rococo styles, based on the use of a large number of sophisticated décor and gilt, are examples of such sources of inspiration.

Refinement and elegant restraint are simultaneously present in European classicism, based on the use of order traditions and antique decor. Another source of inspiration is Art Deco, which has gained popularity among the American and Western European elites through specific aesthetic properties, such as the use of contrasting polychromy, mahogany and ebony in decoration, brass, enamel, silver, polished gemstones, mother-of-pearl, ivory, crystal, skin, etc.

Designers Jaime Hayón, Billy Baldwin, Martyn Lawrence Bullard, Kirill Istomin, Philippe Starck, Karim Rashid, Kelly Wearstler, Piero Fornasetti, Albert Hadley have been actively working in the glamour style. Thus, glamour arose primarily as a stylistic trend - as the expresser of the specific social status of a customer, as a style based on retro styles which personified magnificence and elitism (III. 1). At the same time, it is possible to create glamour interiors not only in international historical styles, but also in purely regional styles - northern national romanticism ('northern modernity'), Ukrainian national romanticism ('Ukrainian modern'), in which magnificence is achieved through the use of a large number of handcrafted products - sculptures, carvings, ceramics, embroidery etc. The spread of glamour style coincided with the intensification of the design development process, which became a form of creativity and gained its place in the process of economic and socio-cultural development. The variety of modern style trends and design trends is explained by the fact that designers actively use the 'artistic alphabet' of retro styles and create their own concepts and developments based on them. Thus, glamour can be considered as one of the dominant factors of the culture of the $20^{\text {th }}-21^{\text {st }}$ centuries.

\section{THE TERM ‘GLAMOUR’ AND ITS DETERMINING FEATURES}

Until recently, the term 'glamour' was attributed primarily to the design of advertising, clothing, show business, mass media and the fashion industry as a whole; however, over time the scope of this concept has significantly expanded and extended to the architectural environment - the interiors of residential and public buildings. The fact that the phenomenon that first manifested itself in the spheres of culture also manifested itself in design can be argued by the direct connection between design and the aesthetic ideals of society, which 
are determined by fashion and the media condition; they also encourage consumers to demand certain goods and services.

Manifestations of glamour are amplified in the societies in which particular social circles have a need to emphasise their specific social status not only by means of the fashion industry or mass media but also by means of design. The attractiveness of the glamour style lies in the possibility of creating a real fairy-tale interior, thus realising the world of our own dreams and illusions, which is promoted by the development of information technologies, finishing materials and lighting engineering.

Despite the prevalence of glamour in interior design, the question of an objective assessment of this phenomenon still remains insufficiently covered in scientific publications, where glamour is analysed from the standpoint of an aesthetic phenomenon, a particular world view and peculiar form of life expression, so primarily from the standpoint of culturology and philosophy. L. Biliakovych, O. Vasylieva, S. Gandla, N. Yehorova ${ }^{1}$, Jean-Mari Kiubilie, Ye. Nikolskyi, K. Tochilov², O. Lahoda, M. Shyrokovskykh and O. Shkolna addressed this issue. The terminology of glamour and its inspirations have been described in scientific sources on art history and artistic culture.

An analysis of the principal elements of the styles of traditional decorative art presented in the encyclopedic publication Design Elements. The development of design and elements of style from the Renaissance to postmodernism edited by Noel Reilly enabled the identification of the main features that have turned glamour into in decorative art. The sources of inspiration for glamour are Renaissance, Baroque, Rococo, Classicism, Art Nouveau and Art Deco. In the dictionary of V. Vlasov Styles in Art, the historical prerequisites of glamour were determined on the basis of etymological, historical, geographical, and art history terms.

S. Bezklubenko defines glamour as an empty concept that personifies the desire for 'beautiful life' and 'external chic' and spread to the wave of the emergence of the subculture of the 'new financial elite' in the countries of Central and Eastern Europe. It is appropriate to this liken to the appearance and flash-like spread of Art Nouveau in the late nineteenth and early twentieth centuries. Modern Art Nouveau emerged for the new ruling elite - the bourgeoisie - and based on radically different aesthetic principles; it also provided a peculiar aesthetic expressing floral decoration with gilding, complex drawing of furniture and even of building structures ${ }^{3}$.

From a philosophical point of view, glamour is a peculiar figurative form of human expression, based on hedonism, which is founded on the principle of obtaining maximum enjoyment from life and providing a setting to avoid negative emotions. Since scientists consider glamour to be an aesthetic phenomenon, a particular form of human expression and a specific worldview - we should recall the works on philosophy and cultural studies of Jean Baudrillard, Yu. Vetoshkina, Jean-Marie Cubilier, O. Lahoda, Ye. Nikolskyi, K. Mironova, D. Rudneva and K. Tochilov ${ }^{4}$. Some scientists considered glamour to be an integral element of modernity, for example, the French philosopher Jean Baudrillard emphasised that art is 
trying to grow through simulation, while subsequently giving way to an artificial museum and corrupted advertising. He thought that the eclectic details incidental to Baroque, in a contemporary context, would only increase the vast number of patterns without semantic meaning.

Ye. Nikolskyi and K. Mironov investigated the phenomenon of glamour in the system of 'high' and 'low' aesthetic concepts and, on the basis of this study, they did not attribute it to the category of the beautiful; however, they noted the permanence of the concept of 'glamour life', while glamour is the creation of visible beauty.

The publication Rural Glamour and Globalization Kitsch by N. Hundorova is indicative of the manifestations of glamour in the post-Soviet space, which the author associates with the image - the self-presentation of the new elite and its nostalgia for the aristocratic past and the attempts to identify themselves with the world of the West ${ }^{5}$.

For the development of research methodology and the creation of a glossary of terms, we applied the method of the system-structural analysis to the works of M. Domin, Yu. Ivashko ${ }^{6}, \mathrm{O}$. Ivashko ${ }^{7}$ and M. Orlenko, where retro styles were considered (Art-Nouveau in the works of $\mathrm{M}$. Domin and Yu. Ivashko ${ }^{8}$ ) and methods of restoration and reconstruction of the interiors of the Baroque, Classicism, Historicism and Art-Nouveau periods (in M. Orlenko's works); we also analysed the concept of art in relation to the architecture of art institutions of a new type - art-clusters (in publications of O. Ivashko) ${ }^{9}$. Because one of the possible directions of glamour is the stylised Moorish style, Rezga Kouider's publications were analysed ${ }^{10}$.

In the research, we used general scientific methods - analysis, synthesis, generalisation, classification and periodisation; and special methods of art analysis, in particular, the historical and comparative method, the principles of scientific certainty, design and art history approaches, as well as an empirical method of project design and project proposal analysis.

Based on the processing of existing publications, the identification of the principles of hedonism, the analysis of recognised styles of the past-analogues of luxury and sophistication compared to modern artistic trends allow us to formulate the defining features of glamour regarding the design sphere (III. 2). In addition to the theoretical works of predecessors, the practical activities of modern designers and their worldview of the phenomenon of glamour were analysed, in particular, the design works of Jaime Hayón, Martyn Lawrence Bullard, M. Yegorova, Kirill Istomin, Kelly Wearstler, Ebria Feinblatt, Albert Hedli, Kelly Hoppen, I. Sushkov and others.

With regard to the sphere of design, the direction of the style of glamour personifies magnificence, representativeness and 'status', without reference to a specific stylistic interpretation of past eras, but at the same time, with the development of its own features in interior design with the active introduction of decorative arts and crafts from wood, ceramics, natural stone, metal, fabrics and draperies (III. 3). This allows us to consider 
glamour as a specific cultural and aesthetic phenomenon with manifestations in various spheres of life; to trace its influence on the various areas of design with the main focus of research being on the design of the subject environment; to identify the principal historical styles that have been modernised within glamour and to reveal the trends in the creation of 'glamourous' interior and the means of artistic expression.

Although we conditionally use the word 'style' with respect to the term 'glamour', it cannot yet be called a fully fledged style alongside Baroque or Classicism; as, in order for a certain phenomenon to become a full and meaningful style, it must go through three stages of development - origin, flourishing, decay and transformation into something else. A similar problem is inherent in Art Nouveau, which, although it is called a style, due to the short duration of its existence, it did not go through all the stages sequentially - often the early and late periods coincided (for example, Art Nouveau in the architecture of Kharkiv).

Referring to the sources of glamour inspiration, we should note the presence of stylised ornamental motifs, grotesque images and modified ornaments that originate from the Flemish and French Renaissance. The medieval gloomy Gothic imposes to glamour, but it does not comply with the philosophy of hedonism; therefore, it is used in a fragmentary, modified way, mainly in the decorative elements: fancy glass, ceramics, utensils, and carved wood. However, Venetian Murano glass is often used as an expression of elite premium-class interiors. Characteristic of the glamour is the decorative motifs of baroque and rococo-rocaille, macarons, cartouches on furniture, utensils, fabrics, wallpaper. Indeed, the aristocratic mansions of the Baroque and Rococo eras became the initial guidelines for glamour through the coexistence of aesthetic soil with a simultaneous combination of exquisite grace and sweetness and, in contrast, oversaturation with elements and decor. Glamour borrowed the tradition of gilding from Baroque and Rococo styles. Glamour was influenced by oriental Japanese and Chinese art, and European Art Nouveau (which, in turn, was mainly developed on the basis of oriental artistic traditions).

\section{GENERAL CONCLUSIONS}

Under current conditions, glamour in interiors is a stylistic combination of different eras. Contemporary designers prefer laconism of architectural forms, modest colours and a contrasting combination while emphasising exclusive elements of decor which are glamorous in style. Through the use of glamorous decor, it is necessary to understand the individual self-valuable objects that complement and accentuate the elitism of the interiordishes, sculpture, works of art, decorative and applied jeweller art, and lighting devices; but by glamorous decorative finishing, it is necessary to understand the auxiliary elements which also make an impact on the interior - decorative accessories, draperies, panels, tabletops, carved decorative elements, embroidery works, stone, crystals and rhinestone decorations. 
In interiors dominated by the style of 'authentic vintage' (French Provence, Italian Tuscany, antique Greek, Victorian English style), preference is given to 'Chebbi-chic' or 'handmade' décor, involving the use of ceramic, wicker, wooden or wrought-iron décor in the design of frames and panels, other furniture items with an underlined glamour due to the effects of aging, patinating or gilding. Retro elements or vintage floral designs are often used.

The glamour of the interiors of Islamic countries stands out by itself; it is most pronounced in the new mosques, palaces of sheikhs, hotels, and business centres of the East. The interiors of the Arab East are characterised by pomposity, magnificence, the application of expensive materials - gold, silver, expensive inlay, marble and gem jade, mosaic panels, wood and stone carvings, ivory, metal elements with oriental ornaments etc. Glamour also manifested itself in the production of brilliant artificial cacti, gilded pineapples, glossy animals and pink flamingos, gold and silver frames, embroideries and inlays mainly of Chinese origin. Sometimes exotic interior elements are used, such as African masks, snakeskin, crocodile or ostrich skin, stuffed exotic animals or birds, ivory in combination with bronze, crystal, mother of pearl, wood and stone. White fur carpets, the leather of dead animals on walls and floors, and interior textiles with decorative accessories are used. 


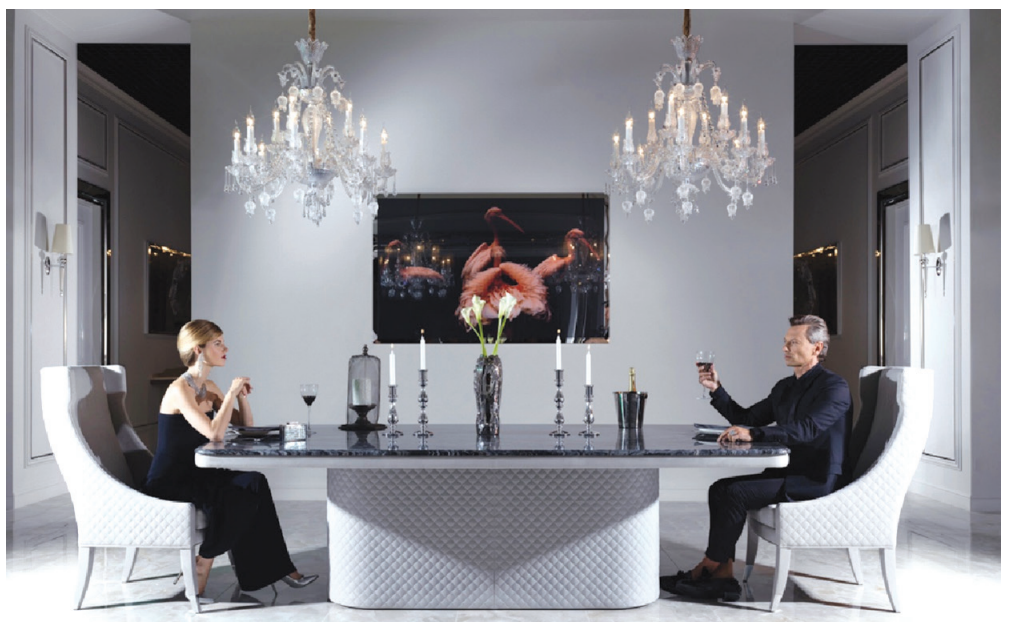

III. 1. Interior of the furniture salon Estetica Vision (Moscow) (photo from the funds of M. Gurenko)

III. 2. Interior of the Estetica Vision furniture salon (Moscow) (photos from the funds of M. Gurenko)

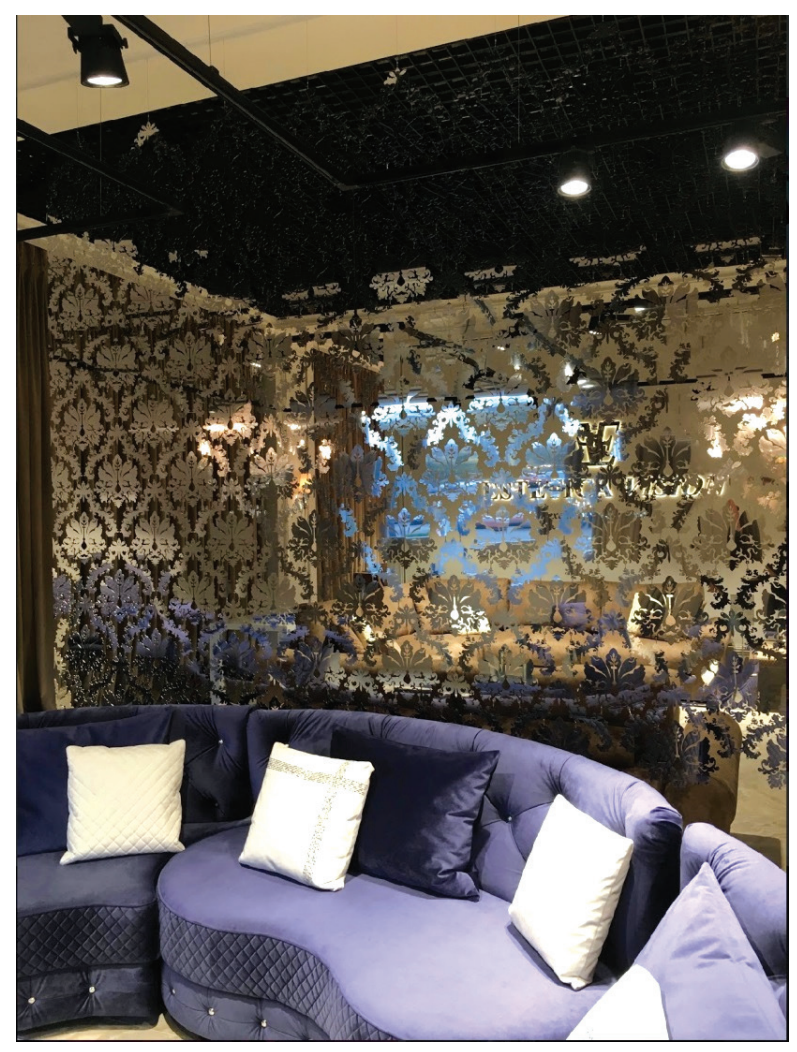




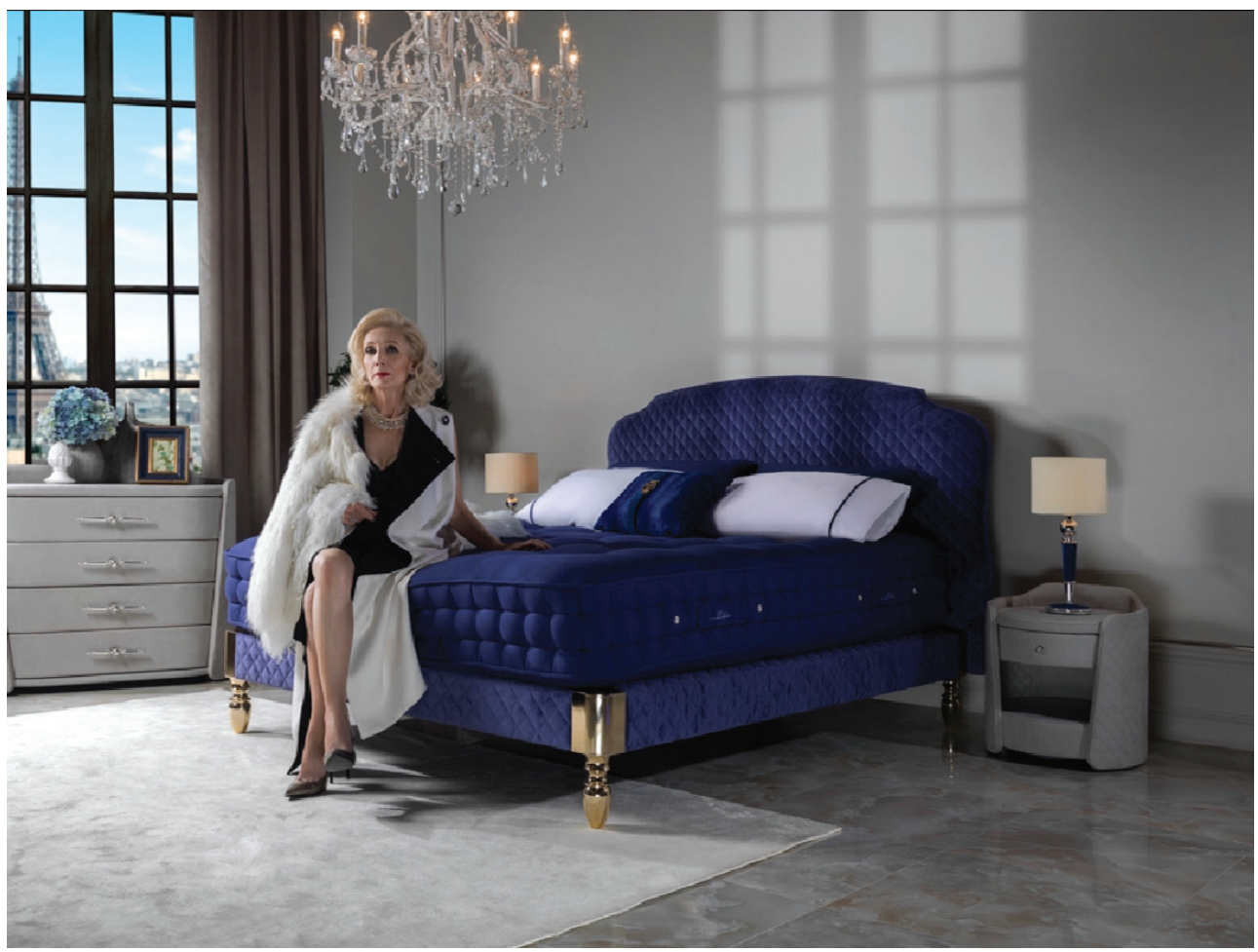

III. 3. Interior of the Estetica Vision furniture salon (Moscow) (photos from the funds of M. Gurenko) 


\section{PRZYPISY}

1 N. Yegorova, Style in the interior: in 10 volumes, vol. 1, Art Deco, vol. 7, Glamour, Publishing House Ukrainian Media Holding, Kyiv 2010.

2 K. Tochilov, Glamour as an aesthetic phenomenon: genesis and historical modifications, extended abstract of PhD dissertation (Philosophy), Moscow 2011; idem, Aesthetics of glamour: ideological foundations and historical continuity, bulletin of the Moscow University of Culture and Arts 5/2010, 91-94.

$3 \mathrm{Yu}$. Ivashko, Interiors of Buildings in Art Nouvau style, Urban planning and territorial planning 22/2005, 107-117; eadem, Kyiv Buildings in the Art Nouveau style, study of history and architecture, Kyiv: Hopak 2006; eadem, Kyiv Buildings with Gothic elements, study of history and architecture, Kyiv: Hopak 2004; eadem, Synthesis of Art in the Art Nouveau Style, Urban planning and territorial planning 23/2006, 89-96; eadem, Japanese culture as one of the origins of European modernity, Current issues of architecture and urban planning 19/2008, 3-10.

4 K. Tochilov, Glamour as an aesthetic... op. cit.; idem, Aesthetics of glamour... op. cit.

5 T. Gundorova, 'Rural Glamour' and Globalization Kitsch, gazeta.zn.ua /CULTURE/selskiy_glamur_i_globalizatsionnyy_kitch.html (accessed: 15.05.2019).

6 Yu. Ivashko, Interiors of Buildings... op. cit.; eadem, Kyiv Buildings in the Art Nouveau style... op. cit.; eadem, Kyiv Buildings with Gothic elements... op. cit.; eadem, Synthesis of Art... op. cit.; eadem, Japanese culture... op. cit.

7 M. Orlenko, O. Ivashko, Art-Clusters as a New Type of Buildings: the Specificity of the Spatial Solution and the Features of Restoration during the Redevelopment Process (The Experience of Poland), Smart Project, Building and City. Środowisko Mieszkaniowe (Housing environment) 21/2017, 109-115.

8 Yu. Ivashko, Interiors of Buildings... op. cit.; eadem, Kyiv Buildings in the Art Nouveau style... op. cit.; eadem, Kyiv Buildings with Gothic elements... op. cit.; eadem, Synthesis of Art... op. cit.; eadem, Japanese culture... op. cit.

9 M. Orlenko, O. Ivashko, op. cit.

${ }^{10}$ R. Kouider R., Yu. Ivashko, Study Methodology of the Architectural Periodization of Algerian Mosques and the Ritual Role of Elements (Mihrab, Minbar, Qibla, Bath for Ablution) in the Islamic Worship Service, Woda i zieleń w architekturze. Środowisko Mieszkaniowe (Housing environment) 22/2018, 28-36. 


\section{REFERENCES}

Gundorova T., 'Rural Glamour' and Globalization Kitsch, gazeta.zn.ua /CULTURE/selskiy_ glamur_i_globalizatsionnyy_kitch.html (accessed: 15.05.2019).

Ivashko Yu., Interiors of Buildings in Art Nouvau style, Urban planning and territorial planning 22/2005, 107-117.

Ivashko Yu., Japanese culture as one of the origins of European modernity, Current issues of architecture and urban planning 19/2008, 3-10.

Ivashko Yu., Kyiv Buildings in the Art Nouveau style, study of history and architecture, Kyiv: Hopak 2006.

Ivashko Yu., Kyiv Buildings with Gothic elements, study of history and architecture, Kyiv: Hopak 2004.

Ivashko Yu., Synthesis of Art in the Art Nouveau Style, Urban planning and territorial planning 23/2006, 89-96.

Kouider R., Ivashko Yu., Study Methodology of the Architectural Periodization of Algerian Mosques and the Ritual Role of Elements (Mihrab, Minbar, Qibla, Bath for Ablution) in the Islamic Worship Service, Woda i zieleń w architekturze. Środowisko Mieszkaniowe (Housing environment) 22/2018, 28-36.

Orlenko M., Ivashko O., Art-Clusters as a New Type of Buildings: the Specificity of the Spatial Solution and the Features of Restoration during the Redevelopment Process (The Experience of Poland), Smart Project, Building and City. Środowisko Mieszkaniowe (Housing environment), 21/2017, 109-115.

Tochilov K., Aesthetics of glamour: ideological foundations and historical continuity, bulletin of the Moscow University of Culture and Arts 5/2010, 91-94.

Tochilov K., Glamour as an aesthetic phenomenon: genesis and historical modifications, extended abstract of PhD dissertation (Philosophy), Moscow 2011.

Yegorova N., Style in the interior: in 10 volumes, vol. 1, Art Deco, Publishing House Ukrainian Media Holding, Kyiv 2010.

Yegorova N., Style in the interior: in 10 volumes, vol. 7, Glamour, Publishing House Ukrainian Media Holding, Kyiv 2010. 